monitoring of the baby should be discussed with the parents because this will often prevent any dilemma about the final decision. ${ }^{14}$ They must be warned that the ideal monitorable to detect central and obstructive apnoea, bradycardia, alveolar hypoventilation, hypoxia, and hypoxaemia-does not exist. They must be told that there are no consistent physiological characteristics of the infant at risk for the sudden infant death syndrome, no simple guidelines for which cases to monitor, and little prospect of a satisfactory controlled trial to define them. The decision is usually resolved by the reality that monitors are now readily available. Some families are reassured by them, despite the lack of evidence for their efficacy. ${ }^{15}$ Families who have previously had a cot death or who have had to contend with more than one near-miss episode may insist on some more practical aid. The choice of monitor is then determined by the reliability of the models. Those with audible clicks for each breath, abdominal movement, or heart beat may be particularly reassuring. Parents can generally be taught the skills of resuscitation quickly and cope well after a few unsettled weeks. ${ }^{16}{ }^{17}$ Monitoring should not be offered unless it is possible to organise 24-hour personal and technical support for the family for several months. Whatever decision is made about home monitoring, the most practical support will remain the continued interest of the medical services in the baby's health and development and a willingness to offer observation in hospital at any time, however trivial the anxiety. Paradoxically, the more freely this is offered, the less likely it seems to be needed.

\section{A N Stanton}

Senior Registrar in Paediatrics,

John Radcliffe Hospital,

Oxford OX3 9DU

${ }^{1}$ Shannon DC, Kelly DH. SIDS and near-SIDS. $N$ Engl $f$ Med 1982; $306: 959-65,1022-8$. (First and second of two parts.)

${ }^{2}$ Kelly DH, Shannon DC, O'Connell K. Care of infants with near-miss sudden infant death syndrome. Pediatrics 1978;61:511-4.

${ }^{3}$ Duffty $\mathrm{P}$, Bryan $\mathrm{MH}$. Home apnea monitoring in near-miss sudden infant death syndrome (SIDS) and in siblings of SIDS victims. Pediatrics 1982;70:69-74.

4 Bergman AB, Beckwith JB, Ray CG. The apnea monitor business. Pediatrics 1975;56:1-3.

${ }^{6}$ Hodgman JE, Hoppenbrouwers T, Geidel S, et al. Respiratory behavior in near-miss sudden infant death syndrome. Pediatrics 1982;69:785-92.

- Stevens LH. Sudden unexplained death in infancy. Observations on a natural mechanism of adoption of the face down position. $A m \mathcal{F} D i s$ Child 1965;110:243-7.

${ }^{7}$ Steinschneider A. Prolonged apnea and the sudden infant death syndrome: clinical and laboratory observations. Pediatrics $1972 ; 50: 646-54$.

${ }^{8}$ Guilleminault C, Korobkin R. Sudden infant death: near-miss events and sleep research. Some recommendations to improve comparability of results among investigators. Sleep 1979;1:423-33.

- Froggatt P, Lynas MA, MacKenzie G. Epidemiology of sudden unexpected death in infants ("cot death") in Northern Ireland. British fournal of Preventive and Social Medicine 1971 ;25:119-34.

${ }^{10}$ Peterson DR, Chinn NM, Fisher LD. The sudden infant death syndrome: repetitions in families. $\mathcal{f}$ Pediatr 1980;97:265-7.

11 Anonymous. What kind of cot death ? Br Med f 1978;i :671-2.

12 Gould JB, James $O$. Management of the near-miss infant: a personal perspective. Pediatr Clin North Am 1979;26:857-65.

${ }^{13}$ Downham MAPS, Stanton AN. Keep cool, baby: the risks of overheating in young babies. Health Visitor $1981 ; 54: 325-8$.

${ }^{14}$ Nelson NM. But who shall monitor the monitor? Pediatrics 1978;61: 663-4.

${ }_{15}$ Lucey JF. False alarms in the nursery. Pediatrics 1978;61:665-6.

16 Black L, Hersher L, Steinschneider A. Impact of the apnea monitor on family life. Pediatrics 1978;62:681-5.

17 Cain LP, Kelly DH, Shannon DC. Parents' perceptions of the psychological and social impact of home monitoring. Pediatrics $1980 ; 66: 37-41$.

\section{The duty of confidence}

The patient looks to his doctor for two essential qualities: one is medical skill; the other is absolute discretion. The two qualities are equally important, for no doctor can practise successfully unless his patients have complete confidence not only in his ability but in the confidentiality of all that they tell him. Despite this, and despite the growing awareness of the consequences of failing to meet accepted standards of medical skill, there seems to be remarkably little understanding of the obligations of confidence.

The governing principle, first stated 25 centuries ago in the Hippocratic Oath, is simple enough: the doctor must preserve secrecy in all he knows about his patients. The obligation of secrecy applies not only to oral confidences but also, and particularly important, to clinical records. The doctor has a duty to keep his patients' records securely to ensure that they are not accessible to others. This will become both more difficult and at the same time more essential as medical records are transferred from the limited confines of the conventional filing system to the vast recesses of the computer.

Inevitably the staff of a practice have some access to clinical records and other confidential matters. It is the doctor's responsibility to ensure that they also understand how important it is to maintain confidentiality. Apart from nurses, most staff will be under no similar professional duty in their own right, but they should be made aware-and ideally this should be an express term of their contracts of employmentthat any disclosure of confidential information will be regarded as gross misconduct justifying summary dismissal.

The general principle is qualified by several exceptions. Firstly, confidential material may be disclosed if the patient gives his consent. Secondly, there may be disclosure when it is undesirable on medical grounds to seek the consent of the patient. A third exception covers the case where the doctor's duty to society as a whole must override his duty to his patient, and a fourth protects approved medical research, provided that the patient is not identified.

The last, and apparently the most misunderstood, of the exceptions to the general principle arises when confidential information is required by due legal process. The circumstances in which the law may override the duty of confidentiality are clearly defined and ought, in the interests of doctor and patient alike, to be clearly understood.

Firstly, certain statutory obligations require doctors to notify the authorities of abortion, drug addiction, and some diseases. The police may also require them to provide information to identify a driver alleged to be guilty of a motoring offence. These obligations are generally well known to the profession and give rise to little difficulty.

The only other circumstance in which a doctor should disclose confidential information without the patient's consent is when ordered to do so by a court of law. A preliminary request from a solicitor, however portentous, should be politely refused. The refusal will often be followed by a subpoena or a summons requiring the doctor to attend at court or to bring to court confidential documents; that should be obeyed. Once at court, and asked to give evidence about a matter which appears to fall within the mantle of professional confidence, the doctor should explain to the judge why he is unwilling to answer the question or, as it may be, to hand over the subpoenaed documents. If the judge orders him to answer, a refusal will place the doctor in contempt of court and make him liable to a fine or a sentence of imprisonment. Refusal to 
answer is not necessarily unethical: compliance with the law is certainly not a breach of the ethical code.

The consequences of an inexcusable breach of the duty of confidentiality, even when committed in the honest but erroneous belief that disclosure was obligatory, are likely to be traumatic. Firstly, the patient whose confidence is abused may bring legal proceedings. He may have a cause of action for breach of the equitable obligation of confidence, or, in appropriate cases, for breach of contract, entitling him to damages or an injunction and an order for costs against the defendant doctor, or both. Secondly, the doctor's breach of duty is likely to lead to a finding by the General Medical Council's Professional Conduct Committee of serious professional misconduct.

Barrister

RICHARd PARKeS

\section{Cavernosography}

Many surgical techniques have been introduced recently to treat male erectile dysfunction, but the correct choice of operation depends on accurate diagnosis. The anatomy of the erectile tissue of the penis may be investigated by cavernosography-the filling of the corpora cavernosa with radio-opaque contrast medium. This is not a new technique; it was first described as a method for showing the pelvic veins, ${ }^{1}$ and 25 years ago May and $\mathrm{Hirt}^{2}$ described the normal radiographic appearances of the corpora cavernosa and also the changes to be found in injuries, inflammation, priapism, and tumours affecting them. The procedure has not, however, been widely used, and there are few reviews of the indications and value of the investigation. ${ }^{34}$

Cavernosography may be performed in outpatients and without anaesthesia. A water-soluble contrast medium is infused, under pressure and with fluoroscopic control, through a small butterfly needle inserted percutaneously into a corpus cavernosus. ${ }^{4}$ The contrast medium will immediately be seen to fill the opposite corpus cavernosus and the superficial and deep veins draining the corpora. The glans penis (corpus spongiosus) is seen to fill in about one-third of patients. Infusion of sufficient fluid will produce tumescence; a tourniquet around the base of the penis is unnecessary and it makes the interpretation of the radiograph most difficult.

A normal erection results from reduced venous drainage from the corpus cavernosus, ${ }^{5}$ possibly in part by the action of valves in the venous drainage system. ${ }^{6}$ Erectile impotence may sometimes be due to abnormal connections between the corpus cavernosus and spongiosus, and in such cases the defect may be corrected surgically. ${ }^{7}$ These communications may be studied when an erection is induced by erotic stimuli. Fistulae may be congenital or acquired as a result of surgical treatment for priapism. ${ }^{8}$

In priapism the defect is in the venous drainage from the corpora cavernosa, though the corpus spongiosus continues to drain normally. ${ }^{8}$ Cavernosography is unnecessary in the acute phase of this condition, but, when treatment has been delayed, it may show that thrombosis has occurred in the erectile tissue, so that shunt procedures are unlikely to prove successful. Cavernosography may be required in assessing impotence after priapism, before surgical ligation of an iatrogenic fistula, or to determine the extent of cavernous fibrosis in patients who may benefit from a penile prosthesis. ${ }^{4}$ The abnormalities seen in Peyronie's disease ${ }^{410}$ seldom need radiological $\underset{3}{3}$ visualisation except in those patients who present with $\stackrel{\mathbb{\Phi}}{\unrhd}$ impotence rather than erectile pain or deformity. Patients with $c$ extensive cavernous fibrosis require the insertion of a penile prosthesis rather than the surgical correction of the erectile deformity.

Cavernosography has been said to be useful in the management of penile injuries. ${ }^{112}$ As with priapism, it is unnecessary in the acute phase but may be of value in the assessment of any erectile deficit due to cavernous fibrosis. ${ }^{4}$ Cavernosography is also useful in assessing the amount of erectile tissue remaining after the traumatic loss of the penis, enabling a rational choice to be made between a lengthening procedure or a phalloplasty. The technique may also help in the assessment of young men with penile abnormalities apparent only on erection. Congenital curvatures, ${ }^{4}$ abnormalities of the suspensory ligament, ${ }^{13}$ or internal fistulae ${ }^{7}$ may be shown in young men with vague histories of erectile dysfunction. The cavernosogram allows both the doctor and patient to inspect the erect penis and discuss the abnormality. This procedure is often sufficient to reassure the patient without recourse to further investigation and unnecessary treatment. Finally, cavernosography has been suggested as a method of assessing the spread of prostatic neoplasia, ${ }^{14}$ but examination with rectal ultrasound is less invasive and probably more effective. ${ }^{15}$

There are few complications from cavernosography, though $\bigcirc$ the formation of a small haematoma is not uncommon. Priapism N has been reported in two patients, both of whom had previously undergone surgery, ${ }^{10}$ but this complication did not occur in a recent series of 68 patients.

JOHN P PRYOR

Consultant Urologist,

King's College Hospital and

St Peter's Hospital,

London,

and Dean,

Institute of Urology,

London WC2H $8 \mathrm{JE}$

${ }^{1}$ De la Pena A. Flebografia de plexos e vasos palvianos en el vivo. Revista Española de Cirugia, Traumatología y Ortopedia 1946;4:245-51.

${ }^{2}$ May F, Hirtl H. Das cavernosogramm. Urol Int 1955;2:120-34.

${ }^{3}$ Ney C, Miller HL, Friedenberg RM. Various applications of corpus cavernosography. Radiology 1976;119:69-73.

${ }^{4}$ Herzberg Z, Kellett MJ, Morgan RJ, Pryor JP. Method, indications and results of corpus cavernosography. Br $\mathcal{F}$ Urol 1981;53:641-4.

${ }^{5}$ Ebbehøj J, Uhrenholdt A, Wagner G. Infusion cavernosography in the human in the unstimulated and stimulated situations and its diagnostic value. In: Zorgniotti AW, Rossi G, eds. Vasculogenic impotence. Springfield, Illinois: CC Thomas, 1980:191-6.

${ }^{6}$ Fitzpatrick TJ, Cooper JF. A cavernosogram study on the valvular competence of the human deep dorsal vein. F Urol 1975;113:497-9.

${ }^{7}$ Ebbehøj J, Wagner G. Insufficient penile erection due to abnormal drainage of the cavernous bodies. Urology 1979;13:507-10.

${ }^{8}$ Fitzpatrick TJ. Spongiosograms and cavernosograms: a study of their value in priapism. $\mathcal{F}$ Urol 1973;109:843-6.

${ }^{9}$ Hamilton RW, Swann JC. Corpus cavernosography in Peyronie's disease. $B r \mathcal{F}$ Urol 1967;39:409-14.

${ }^{10}$ Byström J, Johansson B, Edgren J, Alfthan O, Köhler R. Induratio penis plastica (Peyronie's disease). Cavernosography in assessment of the disease process. Scand $\mathcal{F}$ Urol Nephrol 1974;8:155-61.

11 Datta NS. Corpus cavernosography in conditions other than Peyronie's disease. F Urol 1977;118:588-90.

12 Pliskow RJ, Ohme RK. Corpus cavernosography in acute "fracture" of the penis. $A f R$ 1979;133:331-2.

${ }^{13}$ Pryor JP, Hill JT. Abnormalities of the suspensory ligament of the penis as a cause for erectile dysfunction. $\mathrm{Br} \mathcal{F}$ Urol 1979;51:402-3.

14 Proca $E$, Lucan $M$. Cavernosography in the management of prostatic cancer. Brf Urol 1979;51:397-9.

15 Brooman PJC, Peeling WB, Griffiths GJ, Roberts E, Evans K. A comparison between digital examination and per-rectal ultrasound in the evaluation of the prostate. $B r \mathcal{F}$ Urol $1981 ; 53: 617-20$. 